\title{
Cancer immunotherapy: a brief review of the history, possibilities, and challenges ahead
}

\author{
Stanley J. Oiseth, Mohamed S. Aziz \\ Department of Pathology, American University of the Caribbean School of Medicine, Cupecoy, St. Maarten, Netherlands Antilles.
}

Correspondence to: Dr. Stanley J. Oiseth, Department of Pathology, American University of the Caribbean School of Medicine, 1 University Drive at Jordan Road, Cupecoy, St. Maarten, Netherlands Antilles. E-mail: soiseth@aucmed.edu

How to cite this article: Oiseth SJ, Aziz MS. Cancer immunotherapy: a brief review of the history, possibilities, and challenges ahead. $J$ Cancer Metastasis Treat 2017;3:250-61.

\begin{abstract}
Article history:
Received: 12 Jun 2017

Accepted: 2 Oct 2017

Published: 31 Oct 2017
\end{abstract}

\section{Key words:}

Cancer immunotherapy, immune checkpoint inhibitors, PD-1, programmed death-ligand 1 , cytotoxic T-lymphocyte-associated antigen-4, adoptive cell therapy, cancer vaccines, oncolytic viruses, history of cancer immunology

\begin{abstract}
The knowledge that the body possesses natural defenses to combat cancer existed long before the modern period, with multiple anecdotal reports of tumors miraculously disappearing, sometimes spontaneously or after a febrile or infectious episode. Spontaneous tumor regression of untreated malignant tumors is currently a well-accepted albeit rare phenomenon, and it is recognized that immunosuppression is associated with a higher cancer risk. The treatment of bladder carcinoma by intravesical administration of live attenuated Bacillus CalmetteGuérin bacteria was shown to be very effective in 1976 and is now standard treatment. Effective immunity against cancer involves complex interactions between the tumor, the host, and the environment. Cancer immunotherapy uses various strategies to augment tumor immunity and represents a paradigm shift in treating cancer, since attention has become more focused on the "biologic passport" of the individual tumor rather than the site of origin of the tumor. The different types of cancer immunotherapies discussed here include biologic modifiers, such as cytokines and vaccines, adoptive cell therapies, oncolytic viruses, and antibodies against immune checkpoint inhibitors, such as the co-inhibitory T-cell receptor PD-1 and one of its ligands, programmed death-ligand 1.
\end{abstract}

\section{INTRODUCTION}

Cancer immunotherapy $(\mathrm{Cl})$ is rapidly advancing and can now be considered to be the "fifth pillar" of cancer therapy, joining the ranks of surgery, cytotoxic chemotherapy, radiation, and targeted therapy. The $\mathrm{Cl}$ which has sparked the most interest involves antibodies to inhibitory immune checkpoint molecules. Although they have produced dramatic results in only a subset of some malignancies to date ${ }^{[1]}$, it is difficult to not be very excited about their potential. In a recent meta-analysis of ipilimumab, a monoclonal antibody that targets cytotoxic T-lymphocyte-associated antigen-4 (CTLA-4), a type of immune checkpoint receptor or negative regulator of T-cell immune function, more than $20 \%$ of patients with metastatic melanoma who received a single round of treatment were alive 10 years later with no evidence of disease ${ }^{[2]}$. Before this treatment, the 10 -year survival

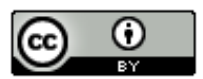

This is an open access article licensed under the terms of Creative Commons Attribution 4.0 International License (https://creativecommons.org/licenses/by/4.0/), which permits unrestricted use, distribution, and reproduction in any medium, as long as the original author is credited and the new creations are licensed under the identical terms.

For reprints contact: service@oaepublish.com

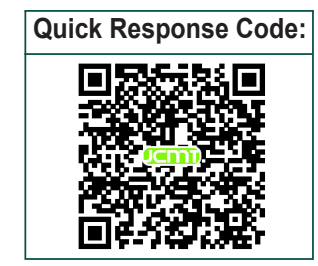


rate was less than $10 \%{ }^{[3]}$. Combination therapy with another immunotherapeutic agent shows even greater promise, as seen when the addition of another checkpoint inhibitor antibody, nivolumab, a monoclonal antibody $(\mathrm{mAb})$ which targets the PD-1 receptor on T-cells, produced a $50 \%$ response rate in metastatic melanoma ${ }^{[4,5]}$. $\mathrm{Cl}$ has also shown effectiveness in other types of malignances, and combinations with different treatment modalities ("immuno-oncology") are also showing remarkable benefits ${ }^{[6,7]}$.

\section{HISTORY OF OUR KNOWLEDGE OF THE IMMUNE SYSTEM'S ROLE IN CANCER}

It has been known for many years that the immune system plays a major role in neoplastic development and control, since patients who are immunosuppressed have a higher risk of cancer, and spontaneous regression of many types of malignant tumors is a rare but wellrecognized phenomenon-occurring in approximately 1 in every 60,000 to 100,000 cancer cases $^{[8-10]}$.

Throughout history there are multiple accounts about tumorous growths regressing or disappearing after an infectious and/or high febrile episode, having been reported from ancient Egypt up to the early 18th century in Europe, but the scientific basis for attempts at modulating the immune system to treat cancer can find its modern roots only in the second half of the 18th century, when histologic confirmation of a malignancy became possible. More than 135 years ago the German physicians Busch ${ }^{[11]}$ and Fehleisen ${ }^{[12]}$ independently noticed regression of tumors in cancer patients after accidental infections by erysipelas. In 1868, Busch was the first to intentionally infect a cancer patient with erysipelas and he noticed shrinkage of the malignancy. Fehleisen ${ }^{[12]}$ repeated this treatment in 1882 and he also eventually identified Streptococcus pyogenes as the causative agent of erysipelas ${ }^{[12,13]}$. In 1891, an American surgeon, William Coley, of the Bone Tumor Service at Memorial Hospital in New York, followed up on his own independent observation of a long-term regression of a sarcoma after an erysipelas infection by starting a 43-year-old project involving the injection of heatinactivated bacteria ("Coley's toxins") into patients with inoperable cancers ${ }^{[14]}$. He reported a significant number of regressions and cures in more than 1,000 patients, many or most with sarcomas, and the method started gaining wide acceptance and notoriety ${ }^{[15]}$ [Figure 1]. His toxins gradually disappeared from use because of several factors, including his failure to follow good scientific protocols and inability to consistently obtain reproducible results. The development of radiation therapy and chemotherapy also contributed to the loss of interest in using this type of therapy to treat
New York Times - July 29, 1908

\section{ERYSIPELAS GERMS ASCURE FOR CANCER}

\author{
Dr. Coley's Remedy of Mixed \\ Toxins Makes One Disease \\ Cast Out the Other. \\ MANY CASES CURED HERE
}
Physician $\mathrm{Has}$ Used the Cure for 15 Years and Treated 430 Cases- Probably 150 Sure Cures.

Follow!ng news from St. Lou's that Following new's from St. Lov's that
two men have been cured of cancer in the City Hospital there by the use of a Iluld discovered by" Dr. Willam B. Coley c1 New York. It came out yesterday that nearly 100 cases of that supposely ir.curable disease have been cure: in this city during the last few years, all through the use of the flutd discovered by Dr. Coley.

Figure 1: An article in a major U.S. newspaper printed in 1908 reflects the widespread attention given to Coley's toxins

cancer. Nonetheless, after no fewer than five marked shifts in attitude toward $\mathrm{Cl}$ since the $1890 \mathrm{~s}^{[16]}$, Coley's principles have been shown to be correct, and the use of bacteria finally found sound justification in 1976 when Morales et al. ${ }^{[17]}$ established the effectiveness of the bacterium Bacillus Calmette-Guérin (BCG) in the treatment of superficial bladder cancer. The underpinnings for this clinical trial include a 1959 study by Old et al. ${ }^{[18]}$ showing the anti-tumor effects of BCG in a mouse model. Besides his work on BCG, Old also performed extensive research on other Cl-related topics, and was a discoverer of tumor necrosis factor in $1975^{[19]}$. Due to their foundational discoveries and lifelong dedication to the field, Coley and Old have each been referred to as the "Father of Immunotherapy", a title which is perhaps best shared.

Even viral infections were believed to have a cancersuppressive effect as far back as 1904 when George Dock at the University of Michigan described a 42-year-old woman with acute leukemia who experienced a temporary remission after a presumed infection with influenza in $1896^{[20]}$. At the same time, a better understanding of the immune system was being developed, including discoveries about cellular and humoral immunity [Table 1].

\section{THE IMMUNE SYSTEM'S ROLE IN ELIMINATING OR CONTROLLING MALIGNANT CELLS}

As a brief background review, the immune system is 


\section{Table 1: Timeline of selected key events in modern cancer immunology, 1868-2017}

\begin{tabular}{|c|c|}
\hline$\overline{\text { Year }}$ & Event \\
\hline 1868 & First report of an intentional infection of a cancer patient with erysipelas by Wilhelm Busch, with notable shrinkage of the tumor ${ }^{[11]}$ \\
\hline 1883 & Elie Metchnikoff publishes a key paper describing phagocytic cells (macrophages) in frogs ${ }^{[102]}$; awarded Nobel Prize in 1908 \\
\hline 1890 & $\begin{array}{l}\text { Discovery of antibodies (diphtheria and tetanus) by Emil von Behring and Kitasato Shibasaburö }{ }^{-103]} \text {; Nobel Prize awarded } t \\
\text { von Behring in } 1901\end{array}$ \\
\hline 1891 & William Coley injected his first of many cancer patients with bacteria, reporting tumor regressions in many of them ${ }^{[14]}$ \\
\hline 1895 & Discovery of complement, by Jules Bordet ${ }^{[104]}$; awarded Nobel Prize 1919 \\
\hline 1897-1901 & Paul Ehrlich "Side-chain" theory of antibody specificity (adaptive immunity, autoimmunity) ${ }^{[105]}$; awarded Nobel Prize in 1908 \\
\hline 1901 & Serological discovery of blood groups, by Karl Landsteiner ${ }^{[106]}$; awarded Nobel Prize in 1930 \\
\hline 1901-08 & Rejection of transplanted tumors in mice, reported by Carl Jensen \& Leo Loeb ${ }^{[107,108]}$ \\
\hline 1914 & Genetic basis for the rejection of transplantable tumors, reported by Clarence Little ${ }^{[1}$ \\
\hline 1909-20 & Establishment of inbred strains of mice by Leonell Strong and Clarence Little ${ }^{[110]}$ \\
\hline 1948 & $\begin{array}{l}\text { First report of histocompatibility antigens being the basis for transplant rejection, by P. Gorer, S. Lyman, \& G. } \\
\text { Nobel Prize awarded jointly to G. Snell,B. Benacerraf, \& J. Dausset in } 1980\end{array}$ \\
\hline 1955 & Natural-Selection Theory of Antibody Formation, first formulated by N. Jerne ${ }^{[112]}$; awarded Nobel Prize in 1984 \\
\hline 1956 & $\begin{array}{l}\text { Discovery of acquired immunological tolerance by R. Billingham, L. Brent \& P.Medawar. Nobel Prize awarded to Medawar \& F. } \\
\text { Burnet in } 1960^{[113,114]}\end{array}$ \\
\hline 1957 & $\begin{array}{l}\text { Immune rejection of transplanted syngeneic tumors (i.e., each tumor is antigenically unique) }{ }^{[115]} \text {. Reported by Richmond Prehn \& } \\
\text { Joan Main. }\end{array}$ \\
\hline 1957 & $\begin{array}{l}\text { Interferon discovered, described as a factor that conferred the property of viral interference }{ }^{[116]} \text {, reported by Alick Isaacs and } \\
\text { Jean Lindenmann. Its anti-leukemic effect is reported in } 1984 .\end{array}$ \\
\hline 1959 & F. Macfarlane Burnet ${ }^{[30-32]}$ \\
\hline 1959 & ;0]; Nobel Prize awarded to both in 1972. \\
\hline 1959 & BCG shown to have anti-tumor effects in a mouse model, reported by Lloyd Old, Donald Clark, \& Baruj \\
\hline 1973 & Ian \& Zanvil Cohn ${ }^{[121]}$; Steinman awarded Nobel Prize in 2011 for discovery \\
\hline 1974 & specificity of cell-mediated immunity by Peter Doherty and Rolf Zinkernagel ${ }^{[122,123]}$; Nobel Prize awarded to \\
\hline 1975 & $\begin{array}{l}\text { antibodies manufactured by George Koehler \& Caesar Milstein }{ }^{[124,125]} \text {; Nobel Prize awarded to Koehler, Milstein \& N. } \\
\text { theoretical contributions) in } 1984\end{array}$ \\
\hline 1975 & oy Lloyd Old, with Elizabeth Carswell, Robert Kassel, S. Green, N. Fiore, \& B. \\
\hline 1975 & absence of prior \\
\hline 1976 & Tonegawa ${ }^{[127,128]}$; awarded Nobel Prize in 1987. \\
\hline 1982 & nes Allison, \\
\hline 1984 & First \\
\hline 1991 & z, et al. ${ }^{[36]}$ \\
\hline 1996 & $\begin{array}{l}\text { Disco } \\
\text { Jame }\end{array}$ \\
\hline 1998 & arding the activation of innate immunity, by R. Medzhitov, P. Preston-Hurlburt, C. Janeway; \& B. Beutler; \\
\hline 2001 & $\begin{array}{l}\text { or T cells, show increased susceptibility to spontaneous and carcinogen-induced } \\
\text { Old, R. Schreiber, et al. }{ }^{[132]}\end{array}$ \\
\hline 2005 & ne, reported by F. Pagès, A. Berger, M. Camus et al. ${ }^{[133]}$ \\
\hline 2010 & nptomat \\
\hline 2010 & $\begin{array}{l}\text { ed T-cells for the treatment of CD19+ hematologic malignancies in humans, reported by W. } \\
\text { e et al. }{ }^{[135]}\end{array}$ \\
\hline 2011 & $\begin{array}{l}\text { Anti-CTLA-4 (ipilimumab), is the first inhibitory checkpoint inhibitor }(\mathrm{ICI}) \text { approved by the FDA for treatment of stage IV } \\
\text { melanoma }^{[136]}\end{array}$ \\
\hline 2012 & $\begin{array}{l}\text { Discovery of the CRISPR/Cas9 system, a simpler and more efficient method of genome editing, reported byJ.A. Doudna \& E. } \\
\text { Charpentier, with M. Jinek, K. Chylinski, I. Fonfara, \& M. Hauer }{ }^{49]}\end{array}$ \\
\hline 2013 & $\begin{array}{l}\text { First use of CRISPR/Cas9 technique in eukaryotic cells, reported by F. Zhang, with L. Cong, F. Ran, D. Cox, S. Lin, R. } \\
\text { Barretto, N. Habib, P. Hsu, X. Wu, W. Jiang, \& L. Marraffini[ }{ }^{[50]}\end{array}$ \\
\hline 2016 & A second class of ICls, anti-PD-1 (pembrolizumab), is approved for the treatment of melanoma ${ }^{[137]}$ \\
\hline 2016 & First characterization of the role of dendritic cell CTLA- 4 in Th- 1 immunity, reported by M. Halpert, \\
\hline 2016 & A third class of ICls, PD-L1(atezolizumab), is approved for treatment of bladder cancer ${ }^{[139]}$ \\
\hline 2016 & First test in humans of CRISPR gene-editing technique for CAR T-cell therapy ${ }^{[51]}$ \\
\hline 2017 & $\begin{array}{l}\text { lase I/Ila study of an inhibitor of indoleamine 2,3-dioxygenase (IDO1), a non-membrane-attached enzyme with a checkpoi } \\
\text { ibitor function, shows promise }{ }^{[95]}\end{array}$ \\
\hline
\end{tabular}

Not all of the events listed are discussed in the text, but all are referenced to the pertinent literature 
classically considered to be comprised of the innate and adaptive arms, although this is a simplification since these arms have overlapping functions and are intimately related. The innate immune system includes dendritic cells, natural killer cells (NK), macrophages, neutrophils, eosinophils, basophils, and mast cells. Innate immune cells do not require prior stimulation by antigens and act as a first line of defense against foreign antigens. The adaptive immune system includes B lymphocytes, CD4 $4^{+}$helper $\mathrm{T}$ lymphocytes, and $\mathrm{CD} 8^{+}$ cytotoxic $T$ lymphocytes (CTLs), and requires formal presentation by antigen-presenting cells (APCs) for its activation $^{[21]}$. The adaptive immune system generates antigen-specific T- and B-cell lymphocytes. The immune system is highly variable between individuals but relatively stable over time within a given person ${ }^{[22]}$.

Each cell is estimated to experience over 20,000 DNA damaging events each day ${ }^{[23]}$, which are normally repaired by specific DNA repair pathways with no lasting effects ${ }^{[24]}$. Cells which are not repaired and which acquire malignant or potentially malignant changes are then usually recognized and killed by the tumor immunosurveillance system. This involves predominantly cell-mediated mechanisms that can differentiate between self and non-self antigens. Since a malignant cell can have more than 11,000 genomic mutations, many new tumor-associated antigens (TAAs) may be expressed ${ }^{[25]}$. TAAs include products of mutated proto-oncogenes, tumor suppressor genes, overexpressed or aberrantly expressed proteins, tumor antigens produced by oncogenic viruses, oncofetal antigens, altered glycolipids and glycoproteins, and cell type-specific differentiation antigens. These new TAAs, or fragments thereof, are presented on the cell surfaces with their major histocompatibility complex (MHC) molecules. However, recognition of an antigenMHC complex by a T-cell antigen receptor is insufficient for the initial activation of naive T-cells, requiring additional costimulatory signals that are provided by the engagement of the CD28 receptor on the T-cell surface with B7 ligand molecules (two of which are CD80 and CD86) on the APCs. This CD28 receptor/B7 ligand combination or "immunological synapse" stimulates the proliferation and function of the T-cells. Many other receptor/ligand combinations are possible between activated T-cells and other cells, including tumor cells, and some of these interactions are inhibitory, such as PD-1/PD-L1 and CTLA-4/B7 ${ }^{[26-29]}$, and are discussed later in this monograph.

Some malignant cells are able to evade the tumor immunosurveillance system by manipulating their own characteristics as well as the cells in their microenvironment to become "successful" tumors; these evasive mechanisms represent the major area of interest in current $\mathrm{Cl}$ research. The concept that the immune system is capable of detecting and killing nascent "non-self" malignant cells was first developed by Burnet ${ }^{[30,31]}$ and Thomas ${ }^{[32]}$ in their cancer immunosurveillance hypothesis. The concept was not accepted initially but it is now considered a component of cancer immunoediting, whereby the surveillance system can determine or "shape" the immunogenicity of the tumor cells which are not eliminated initially[33]. The immunoediting process has been formally divided into three main phases: elimination, equilibrium, and escape. The elimination phase refers to the initial damage and possible destruction of tumor cells by the innate immune system, followed by presentation of the tumor antigens in the cellular debris to dendritic cells which then present them to T-cells and thereby create tumor-specific CD4 ${ }^{+}$ and $\mathrm{CD} 8^{+} \mathrm{T}$-cells. These help destroy the remaining tumor cells if elimination is complete. The equilibrium phase occurs when any tumor cells survive the initial elimination attempt but are not able to progress, being maintained in a state of equilibrium with the immune cells. In the escape phase, cancer cells grow and metastasize due to loss of control by the immune system. The cancer cells which are not eliminated and which escape may do this by expressing fewer antigens on their surfaces or even by losing their MHC class I expression ${ }^{[34]}$. They may also show the ability to protect themselves from T-cell attack by expressing immune checkpoint (IC) molecules on their surfaces like normal cells; these IC molecules are upregulated by cytokines produced by activated T-cells and are part of a normal negative feedback loop to control excessive tissue damage from inflammation by downregulating or suppressing T-cells ${ }^{[35]}$.

The dynamic that exists between the immune system and tumor antigens is a phenomenon recognized relatively recently, since it was only in 1991 that van der Bruggen and colleagues first reported the existence of a human tumor antigen recognized by T-cells ${ }^{[36]}$. They were able to clone the melanoma antigen-encoding gene (MAGE), which encodes an antigen recognized by cytotoxic T-cells. This provided not only proof that the immune system was capable of seeking and destroying tumor cells but also provided the first identification of a molecular target.

The ability of cancer cells to evade immune destruction has been proposed as the eighth hallmark of cancer ${ }^{[37]}$. As noted above, a tumor is able to do this not only by modulating its own cellular characteristics but also by creating its own "tumor microenvironment" by recruiting apparently normal immune cells to help shield it from attack by the immune system. Through the production of various cytokines and chemokines, successful 
cancers and their metastatic derivatives are able to generate an immunosuppressive, protumorogenic, and prometastatic microenvironment by recruiting and "training" immune cells, including macrophages, regulatory T-cells, immature myeloid cells (which become "myeloid-derived suppressor cells"), T helper 17 cells, regulatory B cells, and leukocytes ${ }^{[38]}$. Even before they metastasize, tumors can influence the systemic environment by altering hematopoiesis as well as the tissue parenchyma of organs at distant sites, thereby forming "pre-metastatic niches"[39]. While some cancer immunotherapies have had marked successes in manipulating these tumor microenvironments, the loss of MHC class I expression by a tumor represents a major immunotherapy treatment challenge ${ }^{[40]}$.

The intrinsic immunological ability of an individual to combat cancer has been called the "cancerimmune set point", and is influenced by a complex set of factors involving the tumor, the host, and environmental factors ${ }^{[41]}$. Clinical studies are trying to better characterize these factors to help predict a person's response to immunotherapy, as discussed in the following paragraphs.

\section{BIOLOGIC MODIFIERS: CYTOKINES AND VACCINES}

The term "immunotherapy" encompasses a wide variety of concepts and methods. Older and non-specific immunotherapies include immunostimulatory cytokines such as interleukin-2 (IL-2) and interferon (IFN). L-MTP is a synthetic analogue of a bacterial cell wall that is capable of activating monocytes and macrophages and has had limited success in cancer treatment as reported in other countries; it is not approved by the Food and Drug Administration (FDA) of the USA ${ }^{[42]}$. The only vaccine for cancer which has received approval by the FDA is sipuleucel-T for metastatic castrate-resistant prostate carcinoma. Dendritic cells from the patient are exposed to prostatic acid phosphatase and granulocytemacrophage colony-stimulating factor (GM-CSF) and reinfused into the patient. Treatment results in a 4 -month increase in median survival ${ }^{[43]}$. Sipuleucel-T is a dendritic cell vaccine, while other types of vaccines employ killed tumor cells or selected tumor antigens, and various vaccines may use microorganisms as vectors for delivery. Vaccine trials using multiple neoantigens specific to an individual patient's tumor have shown promise in two small early trials ${ }^{[44]}$. The goal of all of these tumor vaccines is try to expose patients to those tumor antigens which can provoke an antitumor immune response via the generation of tumor specific antibodies and/or T-cells. Vaccines are one type of biologic response modifier, and BCG was the first one to be used in cancer therapy, for treatment of bladder carcinoma ${ }^{[45]}$, where it indirectly increases the expression of tumor antigens after the tumor cells internalize the bacteria. This induces an intense and complex coordinated release of multiple cytokines, including those from $T$ helper 1 cells (IL-2, IL-12, IFN-Y, tumor necrosis factor), as well as those from $\mathrm{T}$ helper 2 cells (IL-4, IL-5, IL-6, IL-10). Macrophages, epithelial cells, and fibroblasts contribute IL-8, and T helper 17 cells release IL-17 ${ }^{[46]}$. This wide array of cytokines then induces antitumor activity mediated by cytotoxic T lymphocytes, natural killer cells, neutrophils, and macrophages.

\section{ONCOLYTIC VIRUSES}

Oncolytic viruses are an emerging class of cancer therapeutics which lie at the junction of biologic therapy and immunotherapy. These viruses are genetically modified to lack virulence against normal cells but are able to invade and lyse cancer cells which have sacrificed many of their normal anti-viral cellular defenses in order to amplify their growth potential. Lysis is only one of multiple mechanisms involved in the viral-induced destruction of cancer cells, which undergo further attack by an immune system stimulated by a plethora of tumor antigens released by lytic destruction ${ }^{[47]}$. The oncolytic virus which was approved by the FDA in 2015 to treat advanced melanoma is a herpes simplex-1 virus (HSV1) named "T-VEC", modified to express GM-CSF which further stimulates proliferation of immune cells. T-VEC is injected directly into areas of melanoma that a surgeon cannot remove. Clinical trials are underway with other oncolytic viruses for treatment of different types of cancer, with some of these trials combined with other types of cancer therapies.

\section{ADOPTIVE CELL THERAPY}

Adoptive cell therapy (ACT) is another type of immunotherapy which mostly involves the isolation and in-vitro expansion of tumor-specific T-cells, followed by infusion back into the cancer patient. These efforts have also extended to using natural killer cells, since they display rapid and potent immunity to solid tumor metastasis and hematological cancers ${ }^{[48]}$.

There are many forms of ACT, including those using techniques such as culturing tumor-infiltrating lymphocytes obtained directly from the tumor; isolating and expanding one particular T-cell or clone; or using T-cells that have been engineered in vitro to potently recognize and attack tumors, which technique is known as chimeric antigen receptor T-cell (CAR T-cell) therapy. The revolutionary CRISPR/Cas9 (or "CRISPR" for 
short) technique is a much simpler and more efficient method of editing genes than previous methods, and was first reported in $2012^{[49]}$. The acronym stands for "Clustered Regularly Interspaced Short Palindromic Repeats", which refers to a method normally used by bacteria and archaea for protection against the invading nucleic acids of viruses and plasmids. In 2013, the method was adapted for use in eukaryotic cells ${ }^{[50]}$, and in late 2016 a group at Szechuan University became the first to use CRISPR-edited cells in humans ${ }^{[51]}$. Other similar trials are scheduled to start in 2017 in the United States. Prior vaccination with a cancer vaccine can also be used, in an attempt to "prime" rare tumor-specific T-cells ${ }^{[52]}$. Although ACT has produced remarkable results in clinical trials with melanoma and hematologic malignancies as well as with solid cancers, some deaths have occurred in the trial phases secondary to marked cytokine release ("cytokine storm", or "cytokine release syndrome") and cerebral edema ${ }^{[53]}$. Researchers are still studying other ways of modifying T-cells to treat cancer. Relapsed and refractory B-cell acute lymphoblastic leukemia in pediatric and young adult patients is the first disease to receive approval from the FDA for CAR T-cell therapy, outside of clinical trials ${ }^{[54]}$.

\section{IMMUNE CHECKPOINTS}

In order to ensure that an immune inflammatory response is not constantly activated once foreign or tumor antigens have stimulated a response, multiple controls or "checkpoints" are in place or activated. These checkpoints are mostly represented by T-cell receptor binding to ligands on cells in the surrounding microenvironment, forming immunological synapses which then regulate the functions of the T-cell, which become specialized, or "polarized", to perform different activities. As noted earlier, initial T-cell activation involves antigen presentation by the MHC molecules on the antigenpresenting cells (APCs) to the corresponding T-cell receptor (TCR) on naive T-cells. The interaction of the costimulatory T-cell receptor CD28 with the B7 ligand is required for full activation, which is tightly regulated or suppressed by inhibitory checkpoint receptor/ligand pairs to avoid collateral damage from autoimmunity ${ }^{[35]}$.

This type of suppression or induced dysfunctionality of T-cells is also referred to as "T-cell exhaustion" and is different from anergy or senescence. Although it is a mostly reversible physiologic protective mechanism against autoimmunity, the first observation of it was made in mice infected with a chronically persistent strain of lymphocytic choriomeningitis virus ${ }^{[55]}$. This T-cell dysfunction was later discovered to exist in multiple other conditions involving persistent antigen exposure by other viruses such as HIV, hepatitis $B$, and hepatitis
$\mathrm{C}$, or by cancer, thereby allowing these agents to avoid detection and destruction by immune cells ${ }^{[35,56-59]}$.

More than twenty checkpoint molecule pairs, both costimulatory and co-inhibitory, have been discovered, including TIGIT/CD155, LAG-3/MHCII, and TIM3/Gal9 , which are variably expressed not only by T-cells but also by other cells of both myeloid and lymphoid derivation ${ }^{[56,60]}$. Some of these molecules are similar to more common or better-known membrane moieties but with important differences: for example, lymphocyteactivated gene-3 (LAG-3) is structurally homologous to CD4 but has a higher binding affinity to MHC class II antigens than CD4. Since these checkpoint molecules are upregulated in suppressed T-cells, they can also be used as markers of "T-cell exhaustion". The two pairs of inhibitory receptor/ligands which have received the most attention in recent years are cytotoxic $T$ lymphocyte-associated antigen-4 (CTLA-4) receptor with B7 ligand, and programmed cell death protein 1 (PD1) receptor with PD1-L1 ligand. The expression of CTLA-4 receptors on activated effector T-cells and regulatory T-cells was reported in 1987 ${ }^{[61]}$. CTLA4 has very high homology to CD28, with a higher competitive binding affinity to B7, causing inhibition of proliferation and IL-2 secretion by T-cells ${ }^{[62]}$. PD-1 was cloned in $1992^{[63]}$, and its ligands PD-L1 and PD$\mathrm{L} 2$, which are members of the B7 ligand family, were later characterized ${ }^{[64-66]}$. Unlike CTLA-4, PD-1 does not interfere with costimulation, but generates signals that prevent phosphorylation of key signaling intermediates in the T-cell, which reduces their activation ${ }^{[67]}$. While B7 ligands are expressed by professional APCs (includes dendritic cells, macrophages and B cells), PD-L1 can be expressed on many cell types, including T-cells, epithelial cells, endothelial cells, and tumor cells after exposure to interferon-gamma, produced later in the immune response by activated T cells. PD-L2 is primarily expressed on dendritic cells and monocytes, but can be induced in a wide variety of other immune cells and nonimmune cells ${ }^{[68]}$.

Since the CTLA-4/B7 synapse acts earlier than the PD1/PDL-1 synapse in the immune response, CTLA4 is considered the "leader" of the immune checkpoint inhibitors, because it stops potentially autoreactive T-cells at the initial or priming stage of naive T-cell activation, occurring chiefly within lymph nodes ${ }^{[62,69]}$. The PD-1/PD-L1 pathway functions during the later effector phase in the periphery and protects the cells found there from T-cell attack, including tumor cells which express PD-L1 ${ }^{[70]}$. The PD1/PD-L1 pathway represents an adaptive immune resistance mechanism that is exerted by tumor cells in response to endogenous anti-tumor activity ${ }^{[71]}$. 


\section{ANTIBODIES TO IMMUNE CHECKPOINT MOLECULES}

In 1996, Leach, Krummel and Allison reported that CTLA-4-blocking monoclonal antibodies (Mabs) could treat tumors in animal models ${ }^{[72]}$. These MAbs became known as "immune checkpoint inhibitors" (ICls), although they should really be called "antiimmune checkpoint inhibitors" if traditional usage in nomenclature could be easily changed. They are receiving much attention recently because they are much less toxic than conventional cancer therapies, are easier to prepare and administer than other types of cancer immunotherapeutics, and have great potential for widespread application.

MAbs that have been approved for clinical use target eitherPD-1, PD-L1, or CTLA-4, which "block the negative blocking" of the T-cells, with a consequent boost of the immune response against cancer cells. Assays of PD-L1 protein expression by immunohistochemistry are used to determine which tumors would best be treated with an anti-PD-L1 antibody, but it is an imperfect measurement practice because there is lack of standardization of methods and it can sometimes be difficult to differentiate PD-L1-positive tumor cells from the other PD-L1-positive cells in the tumor microenvironment ${ }^{[73]}$. Moreover, immunohistochemistry has a lower sensitivity compared to studies measuring PD-L1 mRNA expression ${ }^{[74]}$.

Anti-PD-1 and anti-PD-L1 antibody treatments are currently the most investigated ICls because they have shown less severe toxicity, or high-grade "immunerelated adverse effects" (irAEs), than anti-CTLA-4 antibody treatments $(5-20 \%$ compared to $10-40 \%$ respectively) ${ }^{[75-79]}$. The wide ranges in the percentages of adverse effects reported reflect the variabilities associated with single or multiple drug regimens, dosage levels, and types of malignancies treated. The more common side effects are fatigue (with or without associated endocrinopathies), dermatologic and mucosal toxicities, diarrhea/colitis, and hepatotoxity. Corticosteroids or other immunomodulators can reverse nearly all of the toxic manifestations of these drugs ${ }^{[75-78]}$. Pneumonitis is an uncommon but potentially severe complication, and rarely deaths have occurred ${ }^{[80]}$. As the authors noted in one comprehensive review article about management of immunotherapy toxicities, "This new family of dysimmune toxicities remains largely unknown to the broad oncology community ${ }^{[7]}$ ".

These drugs have powerful effects, as seen when a Phase I trial using an antibody to the CD28 ligand nearly cost the lives of all six healthy volunteers in a British study when a cytokine storm was provoked, associated with multiorgan failure and resuscitation in the intensive care unit ${ }^{[81]}$. Since this reaction occurred after the very first infusion of a dose 500 times smaller than that found safe in animal studies, this study raised awareness of the need to develop better animal models which more closely mimic drug behavior in humans. In addition, there was increased appreciation of the wisdom of restricting the initial testing of a new pharmaceutical to only a few human subjects ${ }^{[82]}$.

The less toxic antibodies to checkpoint inhibitors have shown a great deal of promise and are now approved by the FDA for six malignancies which are in advanced stages - melanoma, lung cancer, renal cell carcinoma, head and neck cancer, urothelial cancer, and Hodgkin's lymphoma - with many other tumor types being investigated in clinical trials ${ }^{[83,84]}$. Some of these trials are using specific antibodies to modulate the function of the more recently discovered inhibitory and co-stimulatory checkpoint molecules.

The immunotherapy/immuno-oncology field has shown such exponential gains in recent times, associated with an accumulation of a dizzying array of complex results arriving from numerous clinical trials, that mechanistic patient studies are necessary to best advance understanding. This is essentially "reverse translational research", or the opposite of the usual "bench to bedside" philosophy, requiring genetic, phenotypic, functional, and immunohistochemical studies of pretreatment, on-treatment, and post-treatment tissues. These are necessary in order to generate hypotheses that can then be tested in animal models and thereby provide more precise biologic pathways about tumor immunity and rejection ${ }^{[85]}$.

Some of the complexities of interacting with the immune system include timing of administration of ICls to coincide with a high inflammatory microenvironment in the tumor to ensure the presence of many potential tumor-fighting $\mathrm{CD}^{+} \mathrm{T}^{-}$-cells${ }^{[86,87]}$. This often correlates with tumor necrosis provoked by prior conventional chemotherapy, and is also related to the number of mutations present in the tumor ("mutational burden"), which is associated with higher antigenicity and correlates positively with response to $\mathrm{ICls}^{[88]}$. Lung cancers occurring in smokers have a higher mutational burden and have shown more responsiveness to $\mathrm{ICls}^{[8]}$. Microsatellite instability-high colorectal cancers, which tend to have a high-mutation/ high-neoantigen load based on owing their genesis to a deficiency in DNA repair, have also been proven to respond well to $\mathrm{ICls}^{[00,91]}$. Even the patient's intestinal bacteria needs to be considered, as noted in two recent reports: in one study of patients with metastatic melanoma treated with anti-PD-1 antibody, the diversity 
and composition of the gut microbiome differed in responders versus non-responders, with the nonresponders showing less diversity and higher abundance of Bacteroidales, while the responders had higher diversity and a higher abundance of Clostridiales ${ }^{[92]}$. Another study of patients with metastatic renal cell carcinoma showed faster tumor progression in the patients who had received broad-spectrum antibiotics up to one month before treatment with $\mathrm{ICls}^{[93]}$.

Not all immune checkpoint or immunomodulatory molecules take the form of a receptor or ligand. Some may be expressed by the cell in a free soluble form, such as indoleamine 2,3-dioxygenase (IDO1), an enzyme produced by some activated macrophages and also overexpressed by many tumors ${ }^{[94]}$. The enzyme depletes tryptophan in the microenvironment, with production of the catabolite kynurenine, which harms the cytotoxic T-cells. Phase I/Ila studies of one IDO1 inhibitor show promise ${ }^{[95]}$.

\section{CONCLUSION}

With the development of the field of cancer immunotherapy, the focus of treatment has shifted from treating the disease site to treating the specific tumor biologic characteristics and its interaction with the intrinsic immunological ability or "cancer immune set-point" of the patient to combat the disease. Since the immune system has the capacity to remember and the ability to detect and destroy tumor variants as they emerge, immunotherapy will always possess inherent advantages over other therapies that lack these two key attributes. The challenges ahead are to discover why immunotherapy treatments work so dramatically well in some cancers and in some patients while not at all in others, and how tumors which were once sensitive to treatment can acquire resistance. Specifically, to be effective, cancer immunotherapy needs to find ways to manipulate the immune system in the (probable majority of) patients who show little or no immune response to their tumors, even to the point where the tumor microenvironment is an "immune desert" with no tumor-infiltrating T-cells ${ }^{[86,87]}$. Breakthrough discoveries will be necessary to be able to consistently elevate a patient's cancer immune set point and to recover MHC class I antigens in those tumors that downregulate them. One recent study with large therapeutic and prognostic implications used the new CRISPR technique to reveal multiple mutations in the tumor genes of individual patients who failed immunotherapy ${ }^{[96]}$. Some of these identified genes may be associated with loss of tumor antigen expression, while others may involve disturbances in tumor cytokine production or T-cell co-stimulation.
The pharmacoeconomics of these treatments also needs to be considered. The cost of the typical treatment using antibodies to $\mathrm{ICls}$ is near $\$ 150,000$ a year. A combination of ipilimumab and nivolumab, approved by the FDA for advanced or inoperable melanoma, has a cost of $\$ 256,000$ a year for patients who respond to the treatment ${ }^{[97]}$. Some relief may be obtained by the entry of at least some less costly biosimilars, which are biological products that must be "highly similar" to the original reference product, per FDA regulations. Biosimilars are usually made by a different/competing company ${ }^{[98]}$.

Immunotherapy drugs are now approved for treatment of multiple cancer types either as first-line treatment or when standard first-line treatment has failed. The FDA has recently approved the anti-PD-1 antibody pembrolizumab for the treatment of any unresectable or microsatellite instability-high or mismatch repairdeficient solid tumors that have progressed after prior treatment and who have no other satisfactory treatment options ${ }^{[99]}$. This is the first time the agency has approved a cancer treatment based on a common biomarker rather than the location of the body where the tumor originated.

Immunotherapies do not yet represent a panacea in cancer therapy since only a minor subset of some cancers respond to some of these treatments, and it is difficult or impossible to determine precisely who will benefit.

Before finishing this brief review, it is proper to recognize the work of Dr. James Allison of Houston's MD Anderson Cancer Center in Texas, the winner of the 2015 Lasker Award, since he is the one who discovered the T-cell receptor in 1982 and went on to develop the field of checkpoint blockage, leading to the breakthrough drug ipilimumab ${ }^{[100,101]}$.

\section{DECLARATIONS}

\section{Authors' contributions}

Both authors contributed equally to this review.

\section{Financial support and sponsorship}

None.

\section{Conflicts of interest}

There are no conflicts of interest.

\section{Patient consent \\ Not applicable.}

\section{Ethics approval}

Not applicable. 


\section{REFERENCES}

1. Gay P, Prasad V. Few people actually benefit from "breakthrough" cancer immunotherapy. Available from: https://www.statnews. com/2017/03/08/immunotherapy-cancer-breakthrough/. [Last accessed on 30 Oct 2017]

2. Schadendorf D, Hodi FS, Robert C, Weber JS, Margolin K, Hamid O, Patt D, Chen TT, Berman DM, Wolchok JD. Pooled analysis of longterm survival data from phase ii and phase iii trials of ipilimumab in unresectable or metastatic melanoma. J Clin Oncol 2015;33:1889-94.

3. Luke JJ, Flaherty KT, Ribas A, Long GV. Targeted agents and immunotherapies: optimizing outcomes in melanoma. Nat Rev Clin Oncol 2017;14:463-82.

4. ASCO Daily News. Available from: https://am.asco.org/checkmate067-longer-follow-shows-melanoma-pfs-still-better-combonivolumabipilimumab. [Last accessed on 30 Oct 2017]

5. Postow MA, Chesney J, Pavlick AC, Robert C, Grossmann K, McDermott D, Linette GP, Meyer N, Giguere JK, Agarwala SS, Shaheen M, Ernstoff MS, Minor D, Salama AK, Taylor M, Ott PA, Rollin LM, Horak C, Gagnier P, Wolchok JD, Hodi FS. Nivolumab and ipilimumab versus ipilimumab in untreated melanoma. $N$ Engl $J$ Med 2015;372:2006-17.

6. Langer CJ, Gadgeel SM, Borghaei H, Papadimitrakopoulou VA, Patnaik A, Powell SF, Gentzler RD, Martins RG, Stevenson JP, Jalal SI, Panwalkar A, Yang JC, Gubens M, Sequist LV, Awad MM, Fiore J, Ge Y, Raftopoulos H, Gandhi L. Carboplatin and pemetrexed with or without pembrolizumab for advanced, non-squamous non-smallcell lung cancer: a harmacody, phase 2 cohort of the open-label KEYNOTE-021 study. Lancet Oncol 2016;17:1497-508.

7. Patel SH, Rimner A, Cohen RB. Combining immunotherapy and radiation therapy for small cell lung cancer and thymic tumors. Transl Lung Cancer Res 2017;6:186-95.

8. Chida K, Nakanishi K, Shomura H, Homma S, Hattori A, Kazui K, Taketomi A. Spontaneous regression of transverse colon cancer: a case report. Surg Case Rep 2017;3:65.

9. Challis GB, Stam HJ. The spontaneous regression of cancer. A review of cases from 1900 to 1987. Acta Oncol 1990;29:545-50.

10. Kucerova P, Cervinkova M. Spontaneous regression of tumour and the role of microbial infection - possibilities for cancer treatment. Anticancer Drugs 2016;27:269-77.

11. Busch W. Aus der Sitzung der medicinischen Section vom 13 November 1867. Berlin Klin Wochenschr 1868;5:137. (in German)

12. Fehleisen F. Ueber die Züchtung der Erysipelkokken auf künstlichem Nährboden und ihre Übertragbarkeit auf den Menschen. Dtsch Med Wochenschr 1882;8:553-4. (in German)

13. Oelschlaeger TA. Bacteria as tumor therapeutics? Bioeng Bugs 2010;1:146-7.

14. Coley WB. The treatment of malignant tumors by repeated inoculations of erysipelas. With a report of ten original cases. $\mathrm{Am} \mathrm{J}$ Medical Sciences 1893;105:487-511.

15. Coley WB. The treatment of sarcoma with the mixed toxins of erysipelas and Bacillus prodigiosus. Boston Med Surg J 1908;158:17582.

16. Parish CR. Cancer immunotherapy: the past, the present and the future. Immunol Cell Biol 2003;81:106-13.

17. Morales A, Eidinger D, Bruce AW. Intracavitary Bacillus CalmetteGuerin in the treatment of superficial bladder tumors. $J$ Urol 1976;116:180-3.

18. Old LJ, Clarke DA, Benacerraf B. Effect of Bacillus Calmette-Guerin infection on transplanted tumours in the mouse. Nature 1959;184:2912.

19. Carswell EA, Old LJ, Kassel RL, Green S, Fiore N, Williamson B. An endotoxin-induced serum factor that causes necrosis of tumors. Proc
Natl Acad Sci U S A 1975;72:3666-70.

20. Larson C, Oronsky B, Scicinski J, Fanger GR, Stirn M, Oronsky A, Reid TR. Going viral: a review of replication-selective oncolytic adenoviruses. Oncotarget 2015;6:19976-89.

21. Abbas AK, Lichtman AH, Pillai S. Properties and Overview of Immune Responses. In: Cellular and Molecular Immunology, 9th edition. Amsterdam: Elsevier; 2017. p. 1-11.

22. Brodin P, Davis MM. Human immune system variation. Nat Rev Immunol 2017;17:21-9.

23. Loeb LA. Human cancers express mutator phenotypes: origin, consequences and targeting. Nat Rev Cancer 2011;11:450-7.

24. Lindahl T, Wood RD. Quality control by DNA repair. Science 1999;286:1897-905

25. Stoler DL, Chen N, Basik M, Kahlenberg MS, Rodriguez-Bigas MA, Petrelli NJ, Anderson GR. The onset and extent of genomic instability in sporadic colorectal tumor progression. Proc Natl Acad Sci U S A 1999;96:15121-6.

26. Vesely MD, Kershaw MH, Schreiber RD, Smyth MJ. Natural innate and adaptive immunity to cancer. Annu Rev Immunol 2011;29:235-71.

27. Wang RF, Wang HY. Immune targets and neoantigens for cancer immunotherapy and precision medicine. Cell Res 2017;27:11-37.

28. Childs RW, Carlsten M. Therapeutic approaches to enhance natural killer cell cytotoxicity against cancer: the force awakens. Nat Rev Drug Discov 2015;14:487-98.

29. Haabeth OA, Tveita AA, Fauskanger M, Schjesvold F, Lorvik KB Hofgaard PO, Omholt H, Munthe LA, Dembic Z, Corthay A, Bogen B. How do CD4 $(+) \mathrm{T}$ cells detect and eliminate tumor cells that either lack or express MHC class II molecules? Front Immunol 2014;5:174.

30. Burnet M. Cancer: a biological approach. III. Viruses associated with neoplastic conditions. IV. Practical applications. Br Med J 1957;1:8417.

31. Burnet FM. The concept of immunological surveillance. Prog Exp Tumor Res 1970;13:1-27.

32. Thomas L. Discussion. In: Lawrence HS, editor. Cellular and Humoral Aspects of the Hypersensitive States. New York, NY: Hoeber-Harper; 1959. p. 529-32.

33. Dunn GP, Bruce AT, Ikeda H, Old LJ, Schreiber RD. Cancer immunoediting: from immunosurveillance to tumor escape. Nat Immunol 2002;3:991-8.

34. Tsukahara T, Kawaguchi S, Torigoe T, Asanuma H, Nakazawa E, Shimozawa K, Nabeta Y, Kimura S, Kaya M, Nagoya S, Wada T, Yamashita T, Sato N. Prognostic significance of HLA class I expression in osteosarcoma defined by anti-pan HLA class I monoclonal antibody, EMR8-5. Cancer Sc 2006;97:1374-80.

35. Sharma P, Hu-Lieskovan S, Wargo JA, Ribas A. Primary, adaptive, and acquired resistance to cancer immunotherapy. Cell 2017;168:70723.

36. van der Bruggen $\mathrm{P}$, Traversari C, Chomez $\mathrm{P}$, Lurquin $\mathrm{C}$, De Plaen E, Van den Eynde B, Knuth A, Boon T. A gene encoding an antigen recognized by cytolytic $\mathrm{T}$ lymphocytes on a human melanoma. Science 1991;254:1643-7.

37. Hanahan D, Weinberg RA. Hallmarks of cancer: the next generation. Cell 2011;144:646-74

38. Kitamura T, Qian BZ, Pollard JW. Immune cell promotion of metastasis. Nat Rev Immunol 2015;15:73-86.

39. McAllister SS, Weinberg RA. The tumour-induced systemic environment as a critical regulator of cancer progression and metastasis. Nat Cell Biol 2014;16:717-27.

40. Garrido F, Aptsiauri N, Doorduijn EM, Garcia Lora AM, van Hall $\mathrm{T}$. The urgent need to recover MHC class I in cancers for effective immunotherapy. Curr Opin Immunol 2016;39:44-51.

41. Chen DS, Mellman I. Elements of cancer immunity and the cancerimmune set point. Nature 2017;541:321-30.

42. Kager L, Pötschger U, Bielack S. Review of mifamurtide in the 
treatment of patients with osteosarcoma. Ther Clin Risk Manag 2010;6:279-86.

43. Gardner TA, Elzey BD, Hahn NM. Sipuleucel-T (Provenge) autologous vaccine approved for treatment of men with asymptomatic or minimally symptomatic castrate-resistant metastatic prostate cancer. Hum Vaccin Immunother 2012;8:534-9.

44. Kaiser J. Personalized tumor vaccines keep cancer in check. Science 2017;356:122.

45. Speil C, Rzepka R. Vaccines and vaccine adjuvants as biological response modifiers. Infect Dis Clin North Am 2011;25:755-72.

46. Fuge O, Vasdev N, Allchorne P, Green JS. Immunotherapy for bladder cancer. Res Rep Urol 2015;7:65-79.

47. Choi AH, O'Leary MP, Fong Y, Chen NG. From benchtop to bedside: a review of oncolytic virotherapy. Biomedicines 2016;4:E18.

48. Guillerey C, Huntington ND, Smyth MJ. Targeting natural killer cells in cancer immunotherapy. Nat Immunol 2016;17:1025-36.

49. Jinek M, Chylinski K, Fonfara I, Hauer M, Doudna JA, Charpentier E. A programmable dual-RNA-guided DNA endonuclease in adaptive bacterial immunity. Science 2012;337:816-21.

50. Cong L, Ran FA, Cox D, Lin S, Barretto R, Habib N, Hsu PD, Wu X, Jiang W, Marraffini LA, Zhang F. Multiplex genome engineering using CRISPR/Cas systems. Science 2013;339:819-23.

51. Cyranoski D. CRISPR gene-editing tested in a person for the first time. Nature 2016;539:479.

52. Xin G, Schauder DM, Jing W, Jiang A, Joshi NS, Johnson B, Cuia W. Pathogen boosted adoptive cell transfer immunotherapy to treat solid tumors. Proc Natl Acad Sci U S A 2017;114:740-5.

53. Offord C. Making car T-cell therapy safer. The Scientist 2017; April 1. Available from: http://www.the-scientist.com/?articles.view/ articleNo/48973/title/Making-CAR-T-Cell-Therapy-Safer/. [Last accessed on 30 Oct 2017]

54. FDA News Release. FDA approval brings first gene therapy to the United States. Available from: https:/www.fda.gov/NewsEvents/ Newsroom/PressAnnouncements/ucm574058.htm. [Last accessed on 30 Oct 2017]

55. Gallimore A, Glithero A, Godkin A, Tissot AC, Plückthun A, Elliott $\mathrm{T}$, Hengartner $\mathrm{H}$, Zinkernagel $\mathrm{R}$. Induction and exhaustion of lymphocytic choriomeningitis virus-specific cytotoxic $\mathrm{T}$ lymphocytes visualized using soluble tetrameric major histocompatibility complex class I-peptide complexes. J Exp Med 1998;187:1383-93.

56. Catakovic K, Klieser E, Neureiter D, Geisberger R. T cell exhaustion: from pathophysiological basics to tumor immunotherapy. Cell Commun Signal 2017;15:1.

57. Mognol GP, Spreafico R, Wong V, Scott-Browne JP, Togher S, Hoffmann A, Hogan PG, Rao A, Trifari S. Exhaustion-associated regulatory regions in CD8+ tumor-infiltrating T cells. Proc Natl Acad Sci U S A 2017;114:E2776-85.

58. Wherry EJ, Kurachi M. Molecular and cellular insights into T cell exhaustion. Nat Rev Immunol 2015;15:486-99.

59. Schietinger A, Greenberg PD. Tolerance and exhaustion: defining mechanisms of T cell dysfunction. Trends Immunol 2014;35:51-60.

60. Tsai HF, Hsu PN. Cancer immunotherapy by targeting immune checkpoints: mechanism of T cell dysfunction in cancer immunity and new therapeutic targets. J Biomed Sci 2017;24:35.

61. Brunet JF, Denizot F, Luciani MF, Roux-Dosseto M, Suzan M, Mattei MG, Golstein P. A new member of the immunoglobulin superfamilyCTLA-4. Nature 1987;328:267-70.

62. Krummel MF, Allison JP. CD28 and CTLA-4 have opposing effects on the response of T cells to stimulation. J Exp Med 1995;182:459-65.

63. Ishida Y, Agata Y, Shibahara K, Honjo T. Induced expression of PD1, a novel member of the immunoglobulin gene superfamily, upon programmed cell death. EMBOJ 1992;11:3887-95.

64. Dong H, Strome SE, Salomao DR, Tamura H, Hirano F, Flies DB,
Roche PC, Lu J, Zhu G, Tamada K, Lennon VA, Celis E, Chen L. Tumor-associated B7-H1 promotes T-cell apoptosis: a potential mechanism of immune evasion. Nat Med 2002;8:793-800.

65. Freeman GJ, Long AJ, Iwai Y, Bourque K, Chernova T, Nishimura H, Fitz LJ, Malenkovich N, Okazaki T, Byrne MC, Horton HF, Fouser L, Carter L, Ling V, Bowman MR, Carreno BM, Collins M, Wood CR, Honjo T. Engagement of the PD-1 immunoinhibitory receptor by a novel B7 family member leads to negative regulation of lymphocyte activation. J Exp Med 2000;192:1027-34.

66. Latchman Y, Wood CR, Chernova T, Chaudhary D, Borde M, Chernova I, Iwai Y, Long AJ, Brown JA, Nunes R, Greenfield EA, Bourque K, Boussiotis VA, Carter LL, Carreno BM, Malenkovich N, Nishimura H, Okazaki T, Honjo T, Sharpe AH, Freeman GJ. PD-L2 is a second ligand for PD-1 and inhibits T cell activation. Nat Immunol 2001;2:261-8.

67. Buchbinder EI, Desai A. CTLA-4 and PD-1 pathways: similarities, differences, and implications of their inhibition. Am J Clin Oncol 2016;39:98-106.

68. Yearley JH, Gibson C, Yu N, Moon C, Murphy E, Juco J, Lunceford J, Cheng J, Chow LQM, Seiwert TY, Handa M, Tomassini JE, McClanahan T. PD-L2 expression in human tumors: relevance to Anti-PD-1 therapy in cancer. Clin Cancer Res 2017;23:3158-67.

69. Fife BT, Bluestone JA. Control of peripheral T-cell tolerance and autoimmunity via the CTLA-4 and PD-1 pathways. Immunol Rev 2008;224:166-82.

70. Pardoll DM. The blockade of immune checkpoints in cancer immunotherapy. Nat Rev Cancer 2012;12:252-64.

71. Chen DS, Mellman I. Oncology meets immunology: the cancerimmunity cycle. Immunity 2013;39:1-10.

72. Leach DR, Krummel MF, Allison JP. Enhancement of antitumor immunity by CTLA-4 blockade. Science 1996;271:1734-6.

73. Mino-Kenudson M. Programmed cell death ligand-1 (PD-L1) expression by immunohistochemistry: could it be predictive and/ or prognostic in non-small cell lung cancer? Cancer Biol Med 2016;13:157-70.

74. Ritprajak P, Azuma M. IIntrinsic and extrinsic control of expression of the immunoregulatory molecule PD-L1 in epithelial cells and squamous cell carcinoma. Oral Oncol 2015;51:221-8.

75. Haanen JBAG, Carbonnel F, Robert C, Kerr KM, Peters S, Larkin J, Jordan K, ESMO Committee. Management of toxicities from immunotherapy: ESMO Clinical Practice Guidelines for diagnosis, treatment and follow-up. Ann Oncol 2017;28:iv119-42.

76. Kroschinsky F, Stölzel F, von Bonin S, Beutel G, Kochanek M, Kiehl M, Schellongowski P; Intensive Care in Hematological and Oncological Patients (iCHOP) Collaborative Group. New drugs, new toxicities: severe side effects of modern targeted and immunotherapy of cancer and their management. Crit Care 2017;21:89.

77. Champiat S, Lambotte O, Barreau E, Belkhir R, Berdelou A, Carbonnel F, Cauquil C, Chanson P, Collins M, Durrbach A, Ederhy S, Feuillet S, François H, Lazarovici J, Le Pavec J, De Martin E, Mateus C, Michot JM, Samuel D, Soria JC, Robert C, Eggermont A, Marabelle A. Management of immune checkpoint blockade dysimmune toxicities: a collaborative position paper. Ann Oncol 2016;27:559-74.

78. Michot M, Bigenwald C, Champiat S, Collins M, Carbonnel F, PostelVinay S, Berdelou A, Varga Bahleda AR, Hollebecque A, Massard C, Fuerea A, Ribrag V, Gazzah A, Armand JP, Amellal N, Angevin E, Noel N, Boutros C, Mateus C, Robert C, Soria JC, Marabelle A, Lambotte O. Immune-related adverse events with immune checkpoint blockade: a comprehensive review. Eur J Cancer 2016;54:139-48.

79. Robert C, Schachter J, Long GV, Arance A, Grob JJ, Mortier L, Daud A, Carlino MS, McNeil C, Lotem M, Larkin J, Lorigan P, Neyns B, Blank CU, Hamid O, Mateus C, Shapira-Frommer R, Kosh M, Zhou H, Ibrahim N, Ebbinghaus S, Ribas A; KEYNOTE-006 investigators. 
Pembrolizumab versus ipilimumab in advanced melanoma. $N$ Engl $J$ Med 2015;372:2521-32.

80. Naidoo J, Wang X, Woo KM, Iyriboz T, Halpenny D, Cunningham J, Chaft JE, Segal NH, Callahan MK, Lesokhin AM, Rosenberg J, Voss MH, Rudin CM, Rizvi H, Hou X, Rodriguez K, Albano M, Gordon RA, Leduc C, Rekhtman N, Harris B, Menzies AM, Guminski AD, Carlino MS, Kong BY, Wolchok JD, Postow MA, Long GV, Hellmann MD. Pneumonitis in patients treated with anti-programmed death-1/ programmed death ligand 1 therapy. J Clin Oncol 2017;35:709-17.

81. Suntharalingam G, Perry MR, Ward S, Brett SJ, Castello-Cortes A, Brunner MD, Panoskaltsis N. Cytokine storm in a phase 1 trial of the anti-CD28 monoclonal antibody TGN1412. $N$ Engl $\mathrm{J} \mathrm{Med}$ 2006;355:1018-28.

82. Attarwala H. TGN1412: from discovery to disaster. J Young Pharm 2010;2:332-6.

83. Iwai Y, Hamanishi J, Chamoto K, Honjo T. Cancer immunotherapies targeting the PD-1 signaling pathway. J Biomed Sci 2017;24:26.

84. Burstein HJ, Krilov L, Aragon-Ching JB, Baxter NN, Chiorean EG, Chow WA, De Groot JF, Devine SM, DuBois SG, El-Deiry WS, Epstein AS, Heymach J, Jones JA, Mayer DK, Miksad RA, Pennell NA, Sabel MS, Schilsky RL, Schuchter LM, Tung N, Winkfield KM, Wirth LJ, Dizon DS. Clinical cancer advances 2017: annual report on progress against cancer from the American Society of Clinical Oncology. J Clin Oncol 2017;35:1341-67.

85. Sharma P. Immune checkpoint therapy and the search for predictive biomarkers. Cancer J 2016;22:68-72.

86. Hegde PS, Karanikas V, Evers S. The where, the when, and the how of immune monitoring for cancer immunotherapies in the era of checkpoint inhibition. Clin Cancer Res 2016;22:1865-74.

87. Gajewski TF. The next hurdle in cancer immunotherapy: overcoming the non-T-cell-inflamed tumor microenvironment. Semin Oncol 2015;42:663-71.

88. SchumacherTN, Schreiber RD. Neoantigens in cancer immunotherapy. Science 2015;348:69-74.

89. Rizvi NA, Hellmann MD, Snyder A, Kvistborg P, Makarov V, Havel JJ, Lee W, Yuan J, Wong P, Ho TS, Miller ML, Rekhtman N, Moreira AL, Ibrahim F, Bruggeman C, Gasmi B, Zappasodi R, Maeda Y, Sander C, Garon EB, Merghoub T, Wolchok JD, Schumacher TN, Chan TA. Cancer immunology. Mutational landscape determines sensitivity to PD-1 blockade in non-small cell lung cancer. Science 2015;348:124-8.

90. Passardi A, Canale M, Valgiusti M, Ulivi P. Immune checkpoints as a target for colorectal cancer treatment. Int J Mol Sci 2017;18:E1324.

91. LealAD, Paludo J, Finnes HD, Grothey A. Response to pembrolizumab in patients with mismatch repair deficient (dMMR) colorectal cancer (CRC). J Clin Oncol 2017;35:3558.

92. Wargo JA, Gopalakrishnan V, Spencer C, Karpinets T, Reuben A, Andrews MC, Tetzlaff MT, Lazar A, Hwu P, Hwu W-J, Glitza IC, Tawbi HA-H, Patel SP, Lee JE, Davies MA, Gershenwald JE, Futreal A, Sharma P, Allison JP, Jenq RR. Association of the diversity and composition of the gut microbiome with responses and survival (PFS) in metastatic melanoma (MM) patients (pts) on anti-PD-1 therapy. $J$ Clin Oncol 2017;35:3008.

93. Derosa L, Routy B, Enot D, Baciarello G, Massard C, Loriot Y, Fizazi K, Escudier BJ, Zitvogel L, Albiges L. Impact of antibiotics on outcome in patients with metastatic renal cell carcinoma treated with immune checkpoint inhibitors. J Clin Oncol 2017;35:abstract 462

94. Mbongue JC, Nicholas DA, Torrez TW, Kim NS, Firek AF, Langridge WH. The role of indoleamine 2, 3-dioxygenase in immune suppression and autoimmunity. Vaccines (Basel) 2015;3:703-29.

95. Siu LL. BMS-986205, an optimized indoleamine 2,3-dioxygenase 1 (IDO1) inhibitor, is well tolerated with potent pharmacodynamics activity, alone and in combination with nivolumab (Nivo) in advanced cancers in a phase I/IIa trial. Presented at: 2017 AACR Annual Meeting; April 1-5, 2017; Washington, DC. Abstract CT116. Available from: http://www.aacr.org/Documents/AACR2017_ProgramGuide. pdf\#search $=$ CT116. [Last accessed on 30 Oct 2017]

96. Patel SJ, Sanjana NE, Kishton RJ, Eidizadeh A, Vodnala SK, Cam M, Gartner JJ, Jia L, Steinberg SM, Yamamoto TN, Merchant AS, Mehta GU, Chichura A, Shalem O, Tran E, Eil R, Sukumar M, Guijarro EP, Day CP, Robbins P, Feldman S, Merlino G, Zhang F, Restifo NP. Identification of essential genes for cancer immunotherapy. Nature 2017;548:537-42.

97. Beasley D. The cost of cancer: new drugs show success at a steep price. Reuters 2017, April 3. Available from: http://www.reuters.com/ article/usa-healthcare-cancer-costs/rpt-the-cost-of-cancer-new-drugsshow-success-at-a-steep-price-idUSL2N1HB06W. [Last accessed on 30 Oct 2017]

98. Shelley S. Oncology: a new era in therapies; same cost concerns Pharmaceutical Commerce. 2016, May 31. Available from: http:// pharmaceuticalcommerce.com/brand-marketing-communications/ oncology-new-era-therapies-cost-concerns/. [Last accessed on $30 \mathrm{Oct}$ 2017]

99. FDA News Release. FDA approves first cancer treatment for any solid tumor with a specific genetic feature. Available from: https://www. fda.gov/newsevents/newsroom/pressannouncements/ucm560167. htm. [Last accessed on 30 Oct 2017]

100. Allison JP. Unleashing the immune system to combat cancer. 2015 Lasker-DeBakey Clinical Medical Research Award. Available from: http://www.laskerfoundation.org/awards/show/unleashing-immunesystem-combat-cancer/. [Last accessed on 30 Oct 2017]

101. Allison JP, McIntyre BW, Bloch D. Tumor-specific antigen of murine T-lymphoma defined with monoclonal antibody. J Immunol 1982;129:2293-300

102. Metchnikoff E. Untersuchungen ueber die mesodermalen phagocyten einiger wirbeltiere. Biologisches Centralblatt 1883;3:560-5. (in German)

103. Von Behring E, Kitasato S. Ueber das Zustandekommen der Diphtherie-Immunität und der Tetanus-Immunität bei Thieren. Dtsch Med Wschr 1890;16:1113-4. (in German)

104. Bordet J. Les Leucocytes et les propriétés du sérum ches les vaccinés Ann de l'Inst Pasteur 1895;ix:462-506. (in French)

105. Ehrlich P. Die Wertbesmessung des Diphterieilserums und deren theoretische Grundlagen. Klinische Jahrbuch 1897;6:299-326. (in German)

106. Landsteiner K. Über Agglutinationserscheinungen normalen menschlichen Blutes. Wien Klin Wochenschr 1901;14:1132-34. (in German)

107. Jensen CO. Experimental studies on cancer in mice. Zentralblatt fur Bakteriologie, Parasitenkunde und Infectionskrankheiten 1903;34:2834 and 122-143. Translated from German, In: Shimkin MB. Some Classics of Experimental Oncology, 50 Selections, 1775-1965 National Institutes of Health (U.S.) Publication No. 80-2150 October 1980, pp 78-105. Available from: https://babel.hathitrust.org/cgi/pt?id $=$ mdp.39015003789719; view $=1$ up;seq=119. [Last accessed on 30 Oct 2017]

108. Loeb L. Ueber die Enstehung eines Sarkoms nach Transplantation eines Adenocarcinoms einer japanischen Maus. Zeitschrift für Krebsforschung 1908;7:80-110. (in German)

109. Little CC. A possible mendelian explanation for a type of inheritance apparently non-mendelian in nature. Science 1914;40:904-6.

110. Strong LC. Inbred mice in science. In: Morse HC III (editor) Origins of inbred mice. NewYork: Academic Press;1978. p. 45-67.

111. Gorer PA, Lyman S, Snell GD. Studies on the genetic and antigenic basis of tumour transplantation: linkage between a histocompatibility gene and "fused" in mice. Proc R Soc Lond 1948;135:499-505. 
112. Jerne NK. The natural-selection theory of antibody formation. Proc Natl Acad Sci U S A 1955;41:849-57.

113. Billingham, R E, Brent, L, Medawar, PB. Quantitative studies on tissue transplantation immunity. III. Actively acquired tolerance. Available from: http://adsabs.harvard.edu/abs/1956RSPTB.239..357B. [Last accessed on 30 Oct 2017]

114. Silverstein AM. The curious case of the 1960 Nobel Prize to Burnet and Medawar. Immunology 2016;147:269-74.

115. Prehn RT, Main JM. Immunity to methylcholanthrene-induced sarcomas. J Natl Cancer Inst 1957;18:769-78.

116. Isaacs A, Lindenmann J. Virus interference. I. The interferon. Proc R Soc Lond B Biol Sci 1957;147:258-67.

117. Porter RR. The hydrolysis of rabbit y-globulin and antibodies with crystalline papain. Biochem J 1959;73:119-26.

118. Edelman GM, Poulik MD. Studies on structural units of the gammaglobulins. J Exp Med 1961;113:861-84.

119. Fleischman JB, Porter RR, Press EM. The arrangement of the peptide chains in gamma-globulin. Biochem $J$ 1963;88:220-8.

120. Edelman GM, Cunningham BA, Gall WE, Gottlieb PD, Rutishauser $\mathrm{U}$, Waxdal MJ. The covalent structure of an entire gamma G immunoglobulin molecule. Proc Natl Acad Sci U S A 1969;63:78-85.

121. Steinman RM, Cohn ZA. Identification of a novel cell type in peripheral lymphoid organs of mice. I. Morphology, quantitation, tissue distribution. J Exp Med 1973;137:1142-62.

122. Zinkernagel RM, Doherty PC. Immunological surveillance against altered self components by sensitised T lymphocytes in lymphocytic choriomeningitis. Nature 1974;251:547-8.

123. Zinkernagel RM, Doherty PC. Restriction of in vitro T cell-mediated cytotoxicity in lymphocytic choriomeningitis within a syngeneic or semiallogeneic system. Nature 1974;248:701-2.

124. Köhler G, Milstein C. Continuous cultures of fused cells secreting antibody of predefined specificity. Nature 1975;256:495-7.

125. Jerne NK. The somatic generation of immune recognition. Eur $J$ Immunol 1971;1:1-9.

126. Herberman RB, Nunn ME, Holden HT, Lavrin DH. Natural cytotoxic reactivity of mouse lymphoid cells against syngeneic and allogeneic tumors. II. Characterization of effector cells. Int J Cancer 1975;16:230-9.

127. Tonegawa S. Reiteration frequency of immunoglobulin light chain genes: further evidence for somatic generation of antibody diversity. Proc Natl Acad Sci US A 1976;73:203-7.

128. Hozumi N, Tonegawa S. Evidence for somatic rearrangement of immunoglobulin genes coding for variable and constant regions. Proc
Natl Acad Sci U S A 1976;73:3628-32.

129. Quesada JR, Reuben J, Manning JT, Hersh EM, Gutterman JU. Alpha interferon for induction of remission in hairy-cell leukemia. $N$ Engl $J$ Med 1984;310:15-8.

130. Medzhitov R, Preston-Hurlburt P, Janeway CA Jr. A human homologue of the Drosophila Toll protein signals activation of adaptive immunity. Nature 1997;388:394-7.

131. Poltorak A, He X, Smirnova I, Liu MY, Van Huffel C, Du X, Birdwell D, Alejos E, Silva M, Galanos C, Freudenberg M, RicciardiCastagnoli P, Layton B, Beutler B. Defective LPS signaling in C3H/ $\mathrm{HeJ}$ and $\mathrm{C} 57 \mathrm{BL} / 10 \mathrm{ScCr}$ mice: mutations in Tlr4 gene. Science 1998;282:2085-8.

132. Shankaran V, Ikeda H, Bruce AT, White JM, Swanson PE, Old LJ, Schreiber RD. IFNgamma and lymphocytes prevent primary tumour development and shape tumour immunogenicity. Nature 2001;410:1107-11.

133. Pagès F, Berger A, Camus M, Sanchez-Cabo F, Costes A, Molidor R, Mlecnik B, Kirilovsky A, Nilsson M, Damotte D, Meatchi T, Bruneval P, Cugnenc PH, Trajanoski Z, Fridman WH, Galon J. Effector memory $\mathrm{T}$ cells, early metastasis, and survival in colorectal cancer. $N$ Engl $J$ Med 2005;353:2654-66.

134. National Cancer Institute. FDA approval for Sipuleucel-T. Available from: https://www.cancer.gov/about-cancer/treatment/drugs/fdasipuleucel-T. [Last accessed on 30 Oct 2017]

135. Qasim W, Zhan H, Samarasinghe S, Adams S, Amrolia P, Stafford S, Butler K, Rivat C, Wright G, Somaa K, Ghorashian S, Pinner D, Ahsan G, Gilmour K, Lucchini G, Inglott S, Mifsud W, Chiesa R, Peggs KS, Chan L, Farzaneh F, Thrasher AJ, Vora A, Pule M, Veys P. Molecular remission of infant B-ALL after infusion of universal TALEN gene-edited CAR T cells. Sci Transl Med 2017;9:eaaj2013.

136. Mansh M. Ipilimumab and cancer immunotherapy: a new hope for advanced stage melanoma. Yale J Biol Med 2011;84:381-9.

137. U.S. Food and Drug Administration. Pembrolizumab (KEYTRUDA) Checkpoint Inhibitor. Available from: https:/www.fda.gov/Drugs/ InformationOnDrugs/ApprovedDrugs/ucm526430.htm. [Last accessed on 30 Oct 2017]

138. Halpert MM, Konduri V, Liang D, Chen Y, Wing JB, Paust S, Levitt JM, Decker WK. Dendritic cell-secreted cytotoxic T-lymphocyteassociated protein-4 regulates the T-cell response by downmodulating bystander surface B7. Stem Cells Dev 2016;25:774-87.

139. U.S. Food and Drug Administration. Atezolizumab (Tecentriq). Available from: https:/www.fda.gov/drugs/informationondrugs/ approveddrugs/ucm525780.htm. [Last accessed on 30 Oct 2017] 